\title{
Морфометричні показники печінки у щурів із модельованим гепатопульмональним синдромом
}

\author{
I. YA. KRYNYTSKA, YU. M. OREL, I. M. KLISHCH \\ SHEI "Ternopil State Medical University by I. Ya. Horbachevsky"
}

\section{MORPHOMETRIC PARAMETERS OF THE LIVER IN RATS WITH MODULATED HEPATOPULMONARY SYNDROME}

\begin{abstract}
В експерименті на щурах із двома моделями гепатопульмонального синдрому проведено дослідження морфометричних показників печінки. Результати проведеного дослідження вказують на глибокі морфофункціональні зміни печінки, які проявилися ушкодженням і загибеллю гепатоцитів, порушеннями гемодинаміки та структурною перебудовою органа зі збільшенням у його складі відносної частки компонентів строми.

In experiments on rats with two models of hepatopulmonary syndrome the morphometric parameters of the liver were studied. Results of the investigation indicate a pronounced morphofunctional changes of the liver: injury and death of hepatocytes, impaired hemodynamics and restructuring of the organ with an increasing in its stock relative proportion of stroma components.
\end{abstract}

Постановка проблеми і аналіз останніх досліджень та публікацій. В наш час прогресивно зростає кількість ускладнень хронічних дифузних захворювань печінки, в тому числі і з боку дихальної системи, які проявляються артеріальною гіпоксемією, що було названо "гепатопульмональним синдромом" (ГПС) [1].

Прогноз при ГПС-несприятливий і ризик смерті у найближчий рік складає 41 \%. Даний синдром можна розглядати як окреме показання до ортотопічної трансплантації печінки [2]. Крім того, оскільки на сучасному етапі патогенез ГПС залишається до кінця не вияснений, то ортотопічна трансплантація печінки є єдиним успішним методом лікування пацієнтів із даною проблемою. Тим не менше, післяопераційна смертність та проміжок між трансплантацією та поліпшенням артеріальної оксигенації збільшуються у хворих із гострою передтрансплантаційною гіпоксемією внаслідок ГПС [3]. Найсильнішим предиктором смерті є передопераційне $\mathrm{PaO}_{2}$ 50 мм рт ст. або менше і перфузійна сцинтиграфія легень і мозку з мозковим поглинанням $20 \%$ і більше [4]. Летальність після проведення трансплантації печінки у пацієнтів з $\mathrm{PaO}_{2}<50$ мм рт. ст. протягом року перевищує $40 \%$ [5]. Тим не менше, якщо раніше гіпоксемію вважали відносним протипоказан- ням до ортотопічної трансплантації печінки, то на сьогодні навпаки - показники $\mathrm{PaO}_{2} \leq 50-60$ мм рт. ст. є прямим показанням до трансплантації [6].

Регресування симптомів ГПС після трансплантації печінки не завжди буває повним (повне лише у 80 \% пацієнтів) і може тривати 6 місяців і більше [2]. Після трансплантації печінки 5-річну тривалість життя мають 76 \% пацієнтів [7]. Інші автори [8, 9] стверджують, що у близько 85,0 \% пацієнтів із ГПС після трансплантації печінки спостерігається значне поліпшення або повне усунення гіпоксемії впродовж 1 року.

Залишаються суперечливими дані про залежність рівня респіраторних змін від ступеня ураження гепатоцитів при хронічних дифузних захворюваннях печінки. За результатами наших попередніх досліджень у щурів із модельованим гепатопульмональним синдромом було встановлено виражений дисбаланс газового складу артеріальної крові, наявність ознак гіпоксемії та порушення кислотно-лужного стану $[10,11]$, що зробило актуальним вивчення ступеня ураження гепатоцитів у тварин із вищевказаною патологією.

Мета роботи: проаналізувати морфометричні показники печінки у щурів із модельованим гепатопульмональним синдромом. 
Матеріали і методи. Досліди проводили на 58 безпородних щурах-самцях масою 180-220 г. У процесі моделювання патології 10 тварин загинули.

Першу експериментальну модель гепатопульмонального синдрому ми створювали шляхом накладання подвійної лігатури на загальну жовчовивідну протоку і подальшого її пересічення скальпелем [12]. Тварин анестезували внутрішньоочеревинним введенням тіопенталу натрію в дозі 40 мг/кг маси тварини. Виконавши розріз під мечоподібним відростком, загальну жовчовивідну протоку відділяли від розташованих поруч тканин, накладали подвійну лігатуру вище і нижче місця планованого перетину. Потім загальну жовчовивідну протоку пересікали скальпелем. У контрольній групі № 1 тварин загальну жовчовивідну протоку було відділено від тканин, але ії не пересікали. Післяопераційну рану пошарово, наглухо зашивали. На 31 -шу добу після операції тварин виводили з експерименту під тіопенталовим наркозом.

Друга експериментальна модель ГПС була створена шляхом 8-тижневого внутрішньошлункового введення олійного розчину $\mathrm{CCl}_{4}(400$ г на 1 л) в дозі 0,5 мл на 100 г маси тіла тварини в перший день експерименту, 0,3 мл на 100 г на третій день експерименту і далі кожного третього дня до закінчення експерименту 0,3 мл на 100 г. Додатково в раціон щурів було введено суміш кукурудзяної муки, смальцю і холестеролу та розчин алкоголю. Контрольна група тварин № 2 перебувала на стандартному раціоні віварію і отримувала внутрішньошлунково оливкову олію в еквівалентній кількості [13].

Утримання тварин та експерименти проводили відповідно до положень “Свропейської конвенції про захист хребетних тварин, які використовуються для експериментальних та інших наукових цілей” [14].

Для гістологічних досліджень шматочки печінки фіксували в $10 \%$ розчині нейтрального формаліну та заливали в парафінові блоки. Готували гістологічні зрізи завтовшки 5-6 мкм і фарбували їх гематоксиліном та еозином. На гістологічних препаратах оцінювали такі морфометричні параметри: діаметр гепатоцитів, діаметр ядер гепатоцитів, ядерно-цитоплазматичний індекс у гепатоцитах, відносний об'єм паренхіми, стромально-паренхіматозний індекс, відносний об'єм центральних вен, відносний об'єм синусоїдів, відносний об'єм портальних трактів та відносний об'єм пошкоджених гепатоцитів [15].

Результати оброблено параметричними методами варіаційної статистики з визначенням t-критерію Стьюдента.

Результати досліджень та їх обговорення. Динаміку змін досліджуваних нами морфометрич- них параметрів печінки ілюструють дані, представлені в таблиці 1.

Встановлено, що у піддослідних тварин контрольної групи № 1 діаметр гепатоцита складав $(14,2 \pm 0,3)$ мкм, діаметр його ядра $(4,9 \pm 0,2)$ мкм, а ядерно-цитоплазматичний індекс $-0,0740 \pm 0,0008$. Структурні співвідношення складових елементів печінки на тканинному рівні організації характеризувалися показниками їх відносного об'єму. Останній становив $(79,1 \pm 1,4) \%$ для паренхіми, $(3,4 \pm 0,2) \%$ - для ушкоджених гепатоцитів, $(9,9 \pm 0,2) \%$ - для центральних вен, $(9,4 \pm 0,2) \%$ для синусоїдів, $(1,2 \pm 0,1) \%$ - для портальних трактів. Стромально-паренхіматозний індекс при цьому дорівнював $0,218 \pm 0,009$.

У контрольній групі № 2 числові величини перелічених вище морфометричних параметрів були практично ідентичними. Діаметр гепатоцитів і їх ядер складав $(15,0 \pm 0,5)$ i $(5,2 \pm 0,2)$ мкм відповідно, ядерно-цитоплазматичний індекс дорівнював $0,0755 \pm 0,001$. Відносний об'єм паренхіми становив $(78,8 \pm 1,6) \%$, ушкоджених гепатоцитів $(4,1 \pm 0,3) \%$, центральних вен - $(10,2 \pm 0,3) \%$, синусоїдів - $(9,0 \pm 0,3) \%$, портальних трактів $(1,3 \pm 0,1) \%$, стромально-паренхіматозний індекс$0,224 \pm 0,008$.

Дистрофічні та некротичні зміни клітин печінкової паренхіми, що мали місце в тварин обох експериментальних груп, проявилися зменшенням розмірів гепатоцитів, їх ядер, а також зміною ядерно-цитоплазматичних співвідношень. Діаметр гепатоцитів у щурів на 31-шу добу після перев'язки загальної жовчовивідної протоки зменшувався на 28,87 \% відносно контролю, у щурів з тетрахлорметаніндукованим цирозом - на $36,00 \%$. В обох випадках різниця між значеннями морфометричного показника у контрольних і досліджуваних групах була статистично достовірною - $\mathrm{p}<0,001$. Поперечник ядра гепатоцита у тварин на 31-шу добу після перев'язки загальної жовчовивідної протоки меншав на $8,16 \%$. При введенні $\mathrm{CCl}_{4}$ цей параметр зменшувався на $21,15 \%$, при цьому $\mathbf{p}<0,01$. Паралельно регресував і ядерно-цитоплазматичний індекс - на 20,95 \% у експериментальній групі № 1 і на $32,98 \%$ у групі № 2 ( $<<0,001$ в обох випадках).

Описані деструктивні зміни гепатоцитів знайшли своє відображення у різкому зменшенні відносного об'єму паренхіми печінки - на 38,6 \% в експериментальній групі № 1 i на 52,6 \% у групі № 2, a також у значному зростанні відносного об' єму ушкоджених гепатоцитів - в 8,7 і 12,4 раза відповідно. Відмінність між перерахованими величинами була статистично достовірною у групах контролю та експериментальних групах $(\mathrm{p}<0,001)$. 

$(\mathrm{M} \pm \mathrm{m})$

Таблиця 1. Морфометричні показники печінки щурів з модельованим гепатопульмональним синдромом

\begin{tabular}{|c|c|c|c|c|}
\hline \multirow[b]{2}{*}{ Морфометричні показники } & \multicolumn{4}{|c|}{ Досліджувані групи } \\
\hline & $\begin{array}{c}\text { контрольна } \\
\text { група №1 } \\
(\mathrm{n}=12)\end{array}$ & $\begin{array}{c}\text { експеримен- } \\
\text { тальна група №1 } \\
(\mathrm{n}=12)\end{array}$ & $\begin{array}{l}\text { контрольна } \\
\text { група №2 } \\
(\mathrm{n}=12)\end{array}$ & $\begin{array}{c}\text { експеримен- } \\
\text { тальна група №2 } \\
(\mathrm{n}=12)\end{array}$ \\
\hline Діаметр гепатоцита, мкм & $14,2 \pm 0,3$ & $\begin{array}{l}10,1 \pm 0,1 \\
\mathrm{p}_{1}<0,001\end{array}$ & $15,0 \pm 0,5$ & $\begin{array}{c}9,6 \pm 0,2 \\
\mathrm{p}_{1}<0,001 \\
\mathrm{p}_{2}<0,05\end{array}$ \\
\hline Діаметр ядра гепатоцита, мкм & $4,9 \pm 0,2$ & $4,5 \pm 0,1$ & $5,2 \pm 0,2$ & $\begin{array}{l}4,1 \pm 0,3 \\
\mathrm{p}_{1}<0,01\end{array}$ \\
\hline $\begin{array}{l}\text { Ядерно-цитоплазматичний } \\
\text { індекс }\end{array}$ & $0,0740 \pm 0,0008$ & $\begin{array}{c}0,0585 \pm 0,0012 \\
\mathrm{p}_{1}<0,001\end{array}$ & $0,0755 \pm 0,001$ & $\begin{array}{c}0,0506 \pm 0,0008 \\
\mathrm{p}_{1}<0,001 \\
\mathrm{p}_{2}<0,001\end{array}$ \\
\hline Відносний об’єм паренхіми, \% & $79,1 \pm 1,4$ & $\begin{array}{l}40,5 \pm 1,0 \\
\mathrm{p}_{1}<0,001\end{array}$ & $78,8 \pm 1,6$ & $\begin{array}{l}26,2 \pm 0,6 \\
\mathrm{p}_{1}<0,001 \\
\mathrm{p}_{2}<0,001\end{array}$ \\
\hline $\begin{array}{l}\text { Відносний об’єм ушкоджених } \\
\text { гепатоцитів, \% }\end{array}$ & $3,4 \pm 0,2$ & $\begin{array}{l}29,7 \pm 0,9 \\
\mathrm{p}_{1}<0,001\end{array}$ & $4,1 \pm 0,3$ & $\begin{array}{l}50,9 \pm 3,0 \\
\mathrm{p}_{1}<0,001 \\
\mathrm{p}_{2}<0,001 \\
\end{array}$ \\
\hline $\begin{array}{l}\text { Відносний об’єм центральних } \\
\text { вен, \% }\end{array}$ & $9,9 \pm 0,2$ & $10,4 \pm 0,4$ & $10,2 \pm 0,3$ & $\begin{array}{l}11,8 \pm 0,3 \\
\mathrm{p}_{1}<0,01 \\
\mathrm{p}_{2}<0,05\end{array}$ \\
\hline Відносний об’єм синусоїдів, \% & $9,4 \pm 0,2$ & $\begin{array}{l}8,9 \pm 0,1 \\
\mathrm{p}_{1}<0,05\end{array}$ & $9,0 \pm 0,3$ & $\begin{array}{l}8,1 \pm 0,2 \\
p_{1}<0,05 \\
p_{2}<0,01\end{array}$ \\
\hline $\begin{array}{l}\text { Відносний об’єм портальних } \\
\text { трактів, \% }\end{array}$ & $1,2 \pm 0,1$ & $\begin{array}{c}2,3 \pm 0,2 \\
\mathrm{p}_{1}<0,001\end{array}$ & $1,3 \pm 0,1$ & $\begin{array}{c}2,9 \pm 0,2 \\
\mathrm{p}_{1}<0,001 \\
\mathrm{p}_{2}<0,05\end{array}$ \\
\hline $\begin{array}{l}\text { Стромально-паренхіматозний } \\
\text { індекс }\end{array}$ & $0,218 \pm 0,009$ & $\begin{array}{c}0,322 \pm 0,010 \\
\mathrm{p}_{1}<0,001\end{array}$ & $0,224 \pm 0,008$ & $\begin{array}{c}0,401 \pm 0,013 \\
\mathrm{p}_{1}<0,001 \\
\mathrm{p}_{2}<0,001 \\
\end{array}$ \\
\hline
\end{tabular}

Примітки:

1) $p_{1}$ - різниця достовірна порівняно 3 контрольними тваринами;

2) $\mathrm{p}_{2}$ - різниця достовірна порівняно з ураженими тваринами.

Розлади печінкової гемодинаміки, які супроводжували модельований ГПС, проявлялися повнокров'ям центральних вен, про що свідчить збільшення їх відносного об'єму. Цей морфометричний покажчик інтенсифікувався відносно контролю на 0,5 \% у першій експериментальній групі і на 1,6 \% у другій. Слід зазначити, що остання відмінність була статистично достовірною $(\mathrm{p}<0,01)$, що вказує на більш виражені дисциркуляторні порушення у щурів із тетрахлорметаніндукованим цирозом.

За рахунок некрозу гепатоцитів і патологічних змін архітектоніки печінкових часточок у піддослідних тварин зменшувався відносний об'єм синусоїдів: на 0,5 \% в експериментальній групі № 1 і на $0,9 \%-$ у групі № 2 . В обох групах різниця була достовірна порівняно 3 контрольними тваринами $(\mathrm{p}<0,05)$.

Активізація склеротичних процесів, явища холестазу (особливо у тварин із пересіченою жовчовивідною протокою), повнокров'я судин - ці пато- логічні зміни зумовили збільшення відносного об' $€$ му портальних трактів. Зростання цього показника відносно контрольних значень було статистично достовірним в обох експериментальних групах (p<0,001) i склало 1,1 \% у групі № 1 i 1,6 \% - у групі № 2 .

Узагальнюючим комплексним індикатором описаних вище патологічних змін печінкової тканини можна вважати стромально-паренхіматозний індекс, який збільшувався в 1,47 раза в експериментальній групі № 1 і у 1,79 раза - в групі № 2 (рис. 1). При цьому числові значення індексу достовірно відрізнялися від тотожних у групах контролю $(\mathrm{p}<0,001)$. Такі трансформації є результатом зростання частки стромальних структур та загибелі гепатоцитів і зменшення об'єму паренхіми.

Зіставляючи між собою значення вивчених нами морфометричних показників печінкової тканини в обох експериментальних групах, встановлено, що всі вони, за винятком діаметра ядра гепатоцита, 

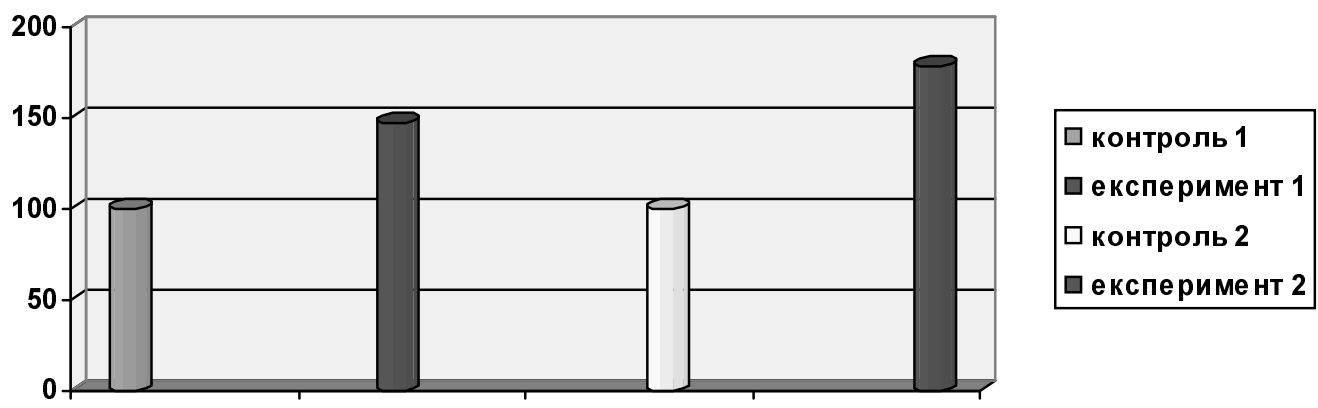

Рис. 1. Зміни стромально-паренхіматозного індексу печінки у відсотках.

достовірно відрізняються між собою $(\mathrm{p}<0,05 \ldots 0,001)$. Таке порівняння свідчить про більш значне ураження печінки при моделюванні ГПС шляхом введення $\mathrm{CCl}_{4}$ порівняно з моделлю, яка передбачає механічне пересічення жовчовивідної протоки.

Висновки. Отже, модельований ГПС супроводжується суттєвими змінами гістоморфометричних параметрів печінкової тканини, що вказує на ії гли-

\section{СПИСОК ЛІТЕРАТУРИ}

1. Rodriguez-Roisin R. Hepatopulmonary syndrome - a liverinduced lung vascular disorder / R. Rodriguez-Roisin, M. J. Krowka// The New England Journal of Medicine. - 2008. - Vol. 358, № 22. P. 2378-2387.

2. Гепатопульмональный синдром: состояние проблемы / Л. Ю. Ильченко, И. Г. Федоров, А. А. Карабиненко [и др.] // СТM. - 2009. - № 1. - С. $84-88$.

3. Liver transplantation for hepatopulmonary syndrome: a tenyear experience in Paris, France / C. Taille, J. Cadranel,A. Bellocq [et al.] // Transplantation. - 2003. - Vol. 75. - P. 1482-1489.

4. Fukushima K. Y. Two cases of hepatopulmonary syndrome with improved liver function following long-term oxygen therapy / K. Y. Fukushima, H. Yatsuhashi, A. Kinishita [et al.] // J. Gastroenterology. - 2007. - Vol. 42 - P. 176-180.

5. Roberts K. E. Genetic risk factors for hepatopulmonary syndrome in patients with advanced liver disease / K. E. Roberts, S. M. Kawut, M. J. Krowka // Gastroenterology. - 2010. Vol. 139. - P. 130-139.

6. Pulmonary-Hepatic vascular Disorders (PHD) / R. RodriguezRoisin, M. J. Krowka, P. Herve [et al.] // Eur. Respir. J. - 2004. Vol. 24. - P. 861-880.

7. Гепатопульмональный синдром / С. В. Курсов, К. Г. Михневич, Н. В. Лизогуб, С. Н. Скороплет // Медицина неотложных состояний. - 2009. - № 5 (24). - С. 35-39.

8. Абрагамович М. О. Гепатопульмональний синдром: особливості патогенезу, діагностики, клінічного перебігу та ліку- бокі морфофункціональні зміни. Якісний характер цих змін проявляється ушкодженням і загибеллю гепатоцитів, порушеннями гемодинаміки та структурною перебудовою органа із збільшенням у його складі відносної частки компонентів строми. Інтенсивність патологічних змін $є$ більш вираженою при моделюванні ГПС шляхом введення тетрахлорметану, що об'єктивно підтверджується величинами всіх досліджуваних морфометричних показників.

вання / М. О. Абрагамович // Український медичний альманах. -2010 . - Т. 13, № 5. - С. 10-13.

9. Lange P. A. Hepatopulmonary syndrome: effects of liver transplantation / P. A. Lange, J. K. Stoller // Clin. Chest Med. 1996. - Vol. 17. - P. 115-123.

10. Криницька І. Я. Зміни газового складу артеріальної крові у щурів з модельованим гепатопульмональним синдромом / I. Я. Криницька, I. М. Кліщ // Вісник наукових досліджень. 2012. - № 4 (69). - С. 72-75.

11. Криницька I. Я. Кислотно-лужний стан крові у щурів 3 модельованим гепатопульмональним синдромом / І. Я. Криницька, І. М. Кліщ // Шпитальна хірургія. - 2012. - № 4. C. $52-55$.

12. Common bile duct ligation in the rat: a model of intrapulmonary vasodilatation and hepatopulmonary syndrome / M. B. Fallon, G. A. Abrams, J. W. McGrath [et al.] // Am. J. Phisiol. - 1997. Vol. 272. - P. 779-784.

13. Multiple pathogenic factor-induced complications of cirrhosis in rats: A new model of hepatopulmonary syndrome with intestinal endotoxemia / Hui-Ying Zhang, De-Wu Han, Zhong-Fu Zhao [et al.] // World J. Gastroenterology. - 2007. - Vol.13 (25). - P. 3500-3507.

14. European convention for the protection of vertebrate animals used for experimental and other scientific purposes. - Council of Europe. Strasbourg. - 1986. - № 123. - 52 p.

15. Автандилов Г. Г. Основы количественной патологической анатомии / Г. Г. Автандилов. - М. : Медицина, 2002. -240 с.

Отримано 22.01.13 